\title{
RECOVERY AND RANGE EXPANSION IN A NORTH CENTRAL UTAH PEREGRINE FALCON POPULATION
}

\author{
Clark S. Monson ${ }^{1}$
}

\begin{abstract}
Aвstract.-Peregrine Falcon numbers in much of the Intermountain West rebounded after a decline during the 1950s, 1960s, and early 1970s. However, recent literature regarding the species suggested that little, if any, growth was occurring in populous north central Utah, which once supported a robust Peregrine Falcon population. A concerted reintroduction effort during the 1980s resulted in establishment of nesting pairs of Peregrine Falcons on artificial towers where they were originally released as nestlings, but traditional nesting cliffs generally remained vacant. More recently, numerous Peregrine Falcon pairs have been observed nesting on cliffs both within and adjacent to their historical range in the region. I combined results from recent literature with numbers gleaned during this study to find that 45 Peregrine Falcon nesting territories are documented for the recovery era in north central Utah.
\end{abstract}

REsumen.-El número de halcones peregrinos, de gran parte de la zona intermontañosa del oeste, aumentó después de su declive durante los años cincuenta, sesenta y principios de los setenta. Sin embargo, literatura reciente acerca de la recuperación de especies en el norte de la región central de Utah, que alguna vez apoyó el fuerte crecimiento de la población del halcón peregrino, sugirió que poco o ningún crecimiento estaba ocurriendo. Durante los años 80 se llevó a cabo un esfuerzo de reintroducción sistemático de halcones, que resultó en el establecimiento de parejas con nidos en torres artificiales donde fueron originalmente liberados como polluelos, los acantilados de anidación tradicionales permanecieron, en general, vacíos. Más recientemente, se han observado numerosas parejas de halcones peregrinos anidando en acantilados tanto dentro como en sitios adyacentes a su rango de distribución histórico en la región. Combinando los resultados de la literatura reciente con los números colectados durante este estudio, documentamos 45 territorios de anidación de halcón peregrino, correspondientes a esta era de recuperación en el área central del norte de Utah.

Wetland environments bordering Great Salt Lake and Utah Lake in north central Utah support large numbers of shorebirds and marsh birds (Behle 1958, Pritchett et al. 1981). This rich avifauna historically supported a substantial population of Peregrine Falcons (Falco peregrinus) (Porter and White 1973). Of the 40 historical Utah Peregrine Falcon nest sites recorded by Porter and White (1973), 21 were within foraging distance of the marshes of one or the other of the 2 lakes. Escarpments along the Wasatch Front and rock outcroppings on several smaller mountain ranges in the region provided nesting sites for the falcons.

From the late 1940s to the early 1970s, biomagnification of DDE, a breakdown product of the insecticide DDT, in peregrines impeded reproduction and imperiled the species across the North American and European continents (Hickey 1969, Ratcliffe 1970). In the early 1970s, Porter and White (1973) noted that Peregrine Falcons in Utah had declined to $<10 \%$ of their former numbers.
Because of its critical status nationally, the Peregrine Falcon was listed as endangered.

DDT was abolished in the United States in 1972. This, along with the captive-rearing and release into the wild of young Peregrine Falcons, facilitated the peregrine's recovery in much of its historical range (Paul 1985, White and Porter 1986, Pagel et al. 1996). In southern Utah a remnant peregrine population persisted through the pesticide era, and recovery occurred there naturally (White and Porter 1986, Enderson et al. 1988). In north central Utah, where the peregrine was extirpated, captive-reared juvenile falcons were annually released (hacked) from 8 towers erected near the shores of Great Salt Lake beginning in 1979 (USFWS 1984). The aim was for the falcons to mature and recolonize traditional nest sites along the nearby Wasatch escarpment (Paul 1985, White 2006). The Utah Division of Wildlife Resources (UDWR) set a goal to establish 10-15 breeding pairs of peregrines from the Utah-Idaho border to central Utah (Paul 1985).

1'Geography Department, 690 SWKT, Brigham Young University, Provo, UT 84602. E-mail: clark_monson@byu.edu 
Paul (1985) reported that 59 peregrines had been released in north central Utah by 1985. Approximately 45 of these peregrines reached independence. However, those that reached sexual maturity (about 3 years after their release) tended to breed on the hack towers and other artificial structures rather than on cliffs (Paul 1985, Bunnell et al. 1997, Kozlowski et al. 2009).

In the mid-1980s, all known nesting peregrines in the region were confined to artificial structures (White and Porter 1986, White 2006). The situation had improved only slightly in 1988 when James Enderson, C.M. White, and team members employed a helicopter to survey cliffs along a $180-\mathrm{km}$ section of the Wasatch Front. They located one active eyrie and a single peregrine near a second historical nest site (White 2006).

Between 1990 and 2002, peregrines breeding at the hack towers reared some 160 additional young birds (Don Paul cited in Kozlowski et al. 2009). In spite of the high productivity, extensive ground and aerial searches of area cliffs by a 2002 survey team revealed no breeding peregrines along the Wasatch Front. However, the survey team located 2 active cliff sites $60 \mathrm{~km}$ west of the Wasatch Mountains (Kozlowski et al. 2009). The paucity of cliffnesting peregrines led the researchers to describe north central Utah's peregrine population as stagnant and much reduced compared to historical figures. I initiated the present study to investigate the current status of the Peregrine Falcon in north central Utah and to determine the extent to which peregrines have been colonizing natural cliffs in the region.

\section{Methods}

\section{Study Area}

The study area includes the mountain ranges and valleys of north central Utah within the eastern Great Basin drainage. Elevation in the study area ranges from $1280 \mathrm{~m}$ along the shores of Great Salt Lake to over 3500 m on the highest mountain summits. The western portions of the study area are arid, receiving as little as $15 \mathrm{~cm}$ of precipitation annually. Higher elevations of the Wasatch Mountains receive up to $155 \mathrm{~cm}$ of precipitation a year (Brough et al. 1987).

The Great Salt Lake and Utah Lake are prominent physical features of the region and are remnants of former Lake Bonneville, an immense pluvial lake that covered much of the eastern Great Basin during the last glacial period. The flat topography of the Salt Lake Valley and Utah Valley is the result of ancient lacustrine sediments from Lake Bonneville (Jackson and Stevens 1981). Streams from the Wasatch Mountains and western Uinta Mountains drain into the lakes.

The boundaries for the present study encompass areas in north central Utah greater than those depicted in Porter and White's (1973) seminal study (Distributions A and B, Fig. 1). For example, Porter and White excluded the Great Salt Lake's islands from the peregrine's breeding range, but I included the islands in the study because peregrines have subsequently nested on several of them. Distributions A and B (Fig. 1) cover approximately $12,160 \mathrm{~km}^{2}$ and $13,110 \mathrm{~km}^{2}$, respectively.

\section{Surveys}

I reviewed historical and contemporary literature regarding Peregrine Falcons in north central Utah. I also questioned local conservation officers, biologists, falconers and other reliable sources regarding recent peregrine sightings and nesting attempts. Additionally, I surveyed 63 historical and potential peregrine nesting cliffs and cliff complexes in the region at least once during the 5-year period from 2011 to 2015. An area of focus was a 140-kmlong segment of the Wasatch Front from Ogden to Santaquin where cliffs in 25 canyons were investigated.

Because of impracticalities, I was not able to search some historical sites, including the high, extensive cliffs north of Ogden. The wetlands adjacent to these cliffs also have occupied hack towers, possibly reducing the likelihood of new nest site discoveries in the area. I began personal observations in early March and continued, as time permitted, until August.

Applying the minimum standard used by Steenhof et al. (1999) in an Idaho Prairie Falcon (Falco mexicanus) survey, I considered a territory active if I observed falcon courtship activity, territorial defense, or adults carrying food to cliffs. I also accepted the presence of recently fledged young as evidence of an active territory. To evaluate the peregrine's status in the study area, I compared the number of recovery era nest sites to the number of historical territories. Herein I refer 


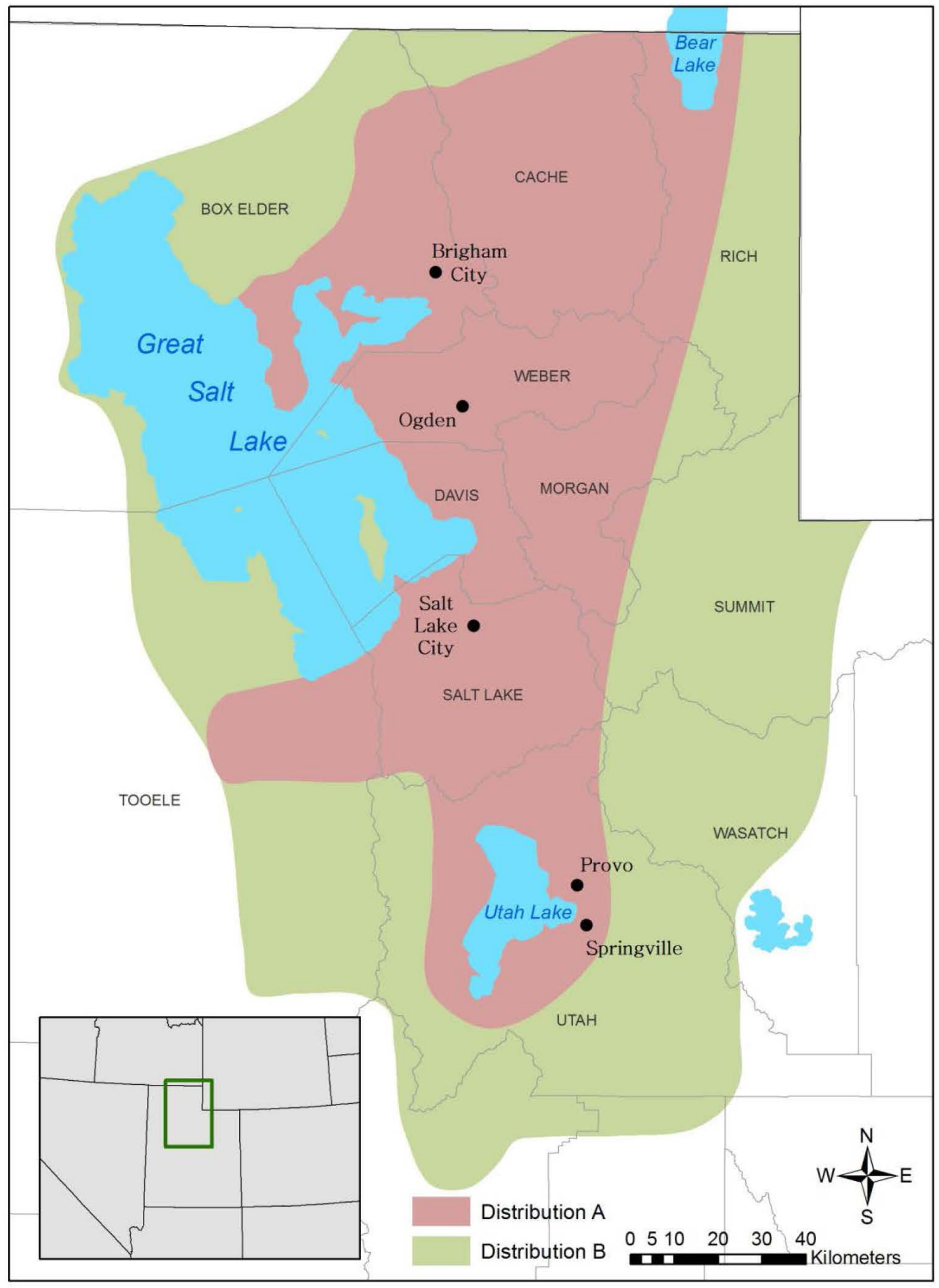

Fig. 1. Breeding distribution of the Peregrine Falcon in north central Utah. Distribution A (red) corresponds to Porter and White's (1973) map of historical peregrine breeding records in Utah. Distribution B (green) shows the peregrine's known and suspected expanded recovery area. 
TABLE 1. Recovery era Peregrine Falcon nest sites in north central Utah. Sites are arranged in alphabetical order by county.

\begin{tabular}{|c|c|c|c|c|c|}
\hline Site & County & Nest type & $\begin{array}{l}\text { Historical } \\
\text { site }\end{array}$ & Distribution & Observer(s) \\
\hline 1 & Box Elder & Hack tower & No & $\mathrm{A}$ & UDWRa $^{\mathrm{a}}$ \\
\hline 2 & Box Elder & Hack tower & No & $\mathrm{A}$ & UDWR \\
\hline 3 & Box Elder & Cliff & No & $\mathrm{B}$ & UDWR, C. White \\
\hline 4 & Box Elder & Cliff & Yes & A & UDWR \\
\hline 5 & Box Elder & Cliff & Yes & $\mathrm{A}$ & UDWR, S. Wooley \\
\hline 6 & Box Elder & Building & No & A & UDWR \\
\hline 7 & Cache & Cliff & No & A & H. Heinz, A. Durso \\
\hline 8 & Cache & Cliff & No & A & A. Kleinhesselink \\
\hline 9 & Davis & Hack tower & No & A & UDWR \\
\hline 10 & Davis & Hack tower & No & A & UDWR \\
\hline 11 & Davis & Hack tower & No & A & UDWR \\
\hline 12 & Davis & Trans. tower & No & A & UDWR \\
\hline 13 & Davis & Trans. tower & No & A & UDWR \\
\hline 14 & Davis & Trans. tower & No & A & UDWR \\
\hline 15 & Davis & Oil refinery & No & A & UDWR \\
\hline 16 & Morgan & Cliff & No & A & P. Shane \\
\hline 17 & Morgan & Cliff & No & A & T. Black \\
\hline 18 & Rich & Cliff & No & $\mathrm{B}$ & C. Monson \\
\hline 19 & Salt Lake & Building/cliffb & No & A & UDWR \\
\hline 20 & Salt Lake & Hack tower & No & A & UDWR \\
\hline 21 & Salt Lake & Cliff & No & A & C. Monson \\
\hline 22 & Salt Lake & Cliff & No & A & C. Monson \\
\hline 23 & Salt Lake & Cliff & No & A & P. Shane \\
\hline 24 & Summit & Cliff & No & $\mathrm{B}$ & P. Shane \\
\hline 25 & Summit & Cliff & No & B & C. Monson \\
\hline 26 & Tooele & Cliff & No & A & P. Shane \\
\hline 27 & Tooele & Cliff & Yes & A & K. Keller \\
\hline 28 & Tooele & Hack tower & No & A & UDWR \\
\hline 29 & Tooele & Cliff & No & B & UDWR \\
\hline 30 & Tooele & Cliff & No & A & UDWR \\
\hline 31 & Tooele & Cliff & No & $\mathrm{A}$ & C. Proctor \\
\hline 32 & Tooele & Cliff & No & A & C. Proctor \\
\hline 33 & Tooele & Cliff & No & A & C. Proctor \\
\hline 34 & Utah & Cliff & No & A & P. Shane, others \\
\hline 35 & Utah & Cliff & No & $\mathrm{A}$ & C. Monson \\
\hline 36 & Utah & Cliff & Yes & $\mathrm{A}$ & P. Shane, L. Taylor \\
\hline 37 & Utah & Cliff & Yes & A & UDWR, L. Taylor \\
\hline 38 & Utah & Cliff & No & A & UDWR \\
\hline 39 & Utah & Cliff & No & $\mathrm{B}$ & J. Tanner, S. Clark \\
\hline 40 & Utah & Cliff & No & $\mathrm{A}$ & W. Whaley \\
\hline 41 & Utah & Cliff & No & A & C. Monson \\
\hline 42 & Utah & Cliff & Yes & A & C. Monson \\
\hline 43 & Wasatch & Cliff & No & $\mathrm{B}$ & C. Monson \\
\hline 44 & Weber & Cliff & Yes & A & C. Monson \\
\hline 45 & Weber & Hack tower & No & A & UDWR \\
\hline
\end{tabular}

aUtah Division of Wildlife Resources

bDuring several years of extensive renovations to the Joseph Smith Memorial Building in downtown Salt Lake City, the Peregrine Falcons occupied a cliff site at a nearby quarry.

to 3 time periods regarding Peregrine Falcons in Utah: the historical era, the pesticide era, and the recovery era. I define the historical era from 1898 (when the first Utah peregrine eyrie was documented) to 1948 . The pesticide era comprises the years from 1949 to 1972. Although deleterious effects of DDT lingered beyond its abatement in 1972, I define the recovery era as extending from 1973 to the present.

\section{RESUlts}

I recorded 24 new Peregrine Falcon nest sites in north central Utah. Surveyed individuals communicated locations for 16 of the 24 sites, while I located the remaining 8 sites. The 24 new sites combined with the 21 territories recorded previously make 45 locations where recovery era peregrines have nested (Table 1). Of the 45 nest sites, 38 occur in the 


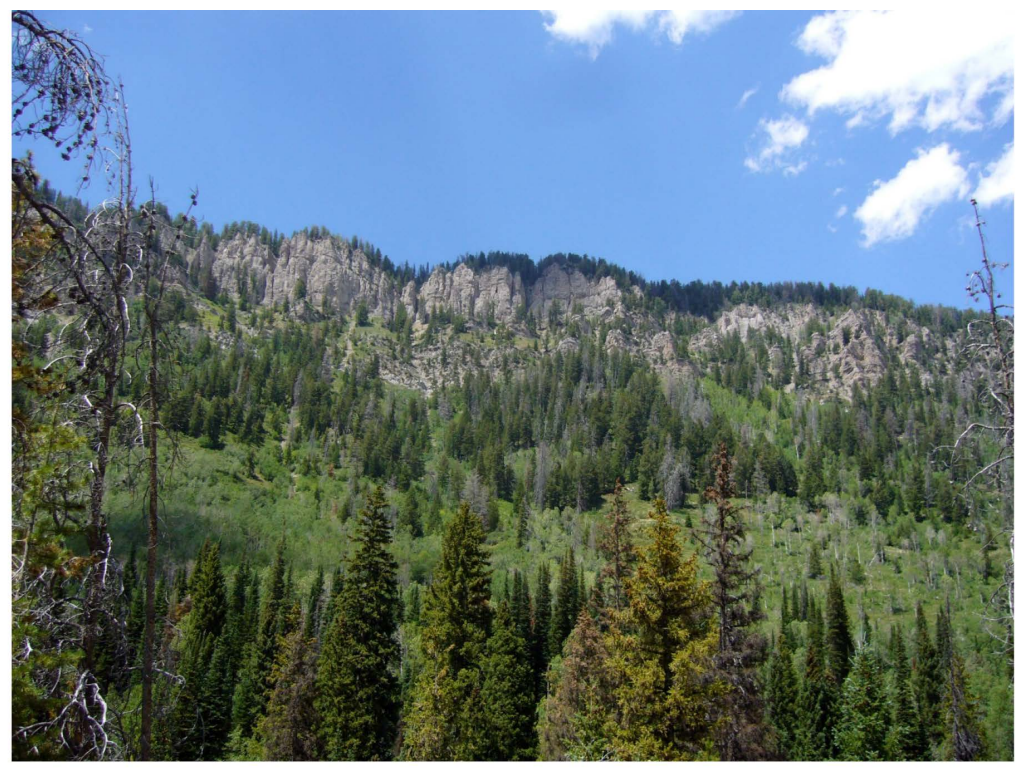

Fig. 2. Peregrine nesting cliff, Summit County, Utah.

historical range of the species (Distribution A), while 7 were found in the expanded range (Distribution B, Fig. 1). Twenty-two of the 24 eyries recorded during this study were on cliffs, mainly in deep canyons. Four newly occupied peregrine sites were reactivated historical eyries (Table 1). Cliff heights ranged from $25 \mathrm{~m}$ to approximately $400 \mathrm{~m}$. Elevations of most nest sites were below $1800 \mathrm{~m}$, but 5 sites occurred at elevations between $2400 \mathrm{~m}$ and $2750 \mathrm{~m}$ (Fig. 2). Two nest sites were on artificial structures: an electrical transmission tower and a landing atop a steel stairway at an oil refinery (Bob Walters personal communication).

Of the 8 peregrine nest sites I located, I found one in 2011 (Fig. 3), one in 2012, 3 in 2014 , and 3 in 2015. Time devoted to search efforts was approximately equal in all 5 years of the study. All 3 nest sites located in 2015 occurred on cliffs that had also been searched in 2011. One of these cliffs was investigated every year of the study before finally becoming occupied in 2015. It was not possible to definitively determine the discovery year of all 16 nest sites ascertained through communications with other individuals, but most, if not all, were found between 2007 and 2013.

Density figures for 13 recovery era territories, irrespective of occupancy, along a 209-km section of the Wasatch Front, was one site per $16.1 \mathrm{~km}$. The average distance between territories diminished to $8.4 \mathrm{~km}$ when the 13 artificial sites among the wetlands of Great Salt Lake were included. In 2015 I observed 7 occupied nest sites along a $105-\mathrm{km}$ portion of the 209-km-long section of the Wasatch Front for an average distance of $15 \mathrm{~km}$ between active territories.

The density of recovery era peregrine territories for Distribution A (Fig. 1) was one site per $320 \mathrm{~km}^{2}$. The density of recovery era peregrine territories for Distributions A and B combined (Fig. 1) was one site per $562 \mathrm{~km}^{2}$.

\section{Discussion}

The findings of the present study are noteworthy because the Wasatch Front was perhaps the last of the historically known regions with a substantial peregrine population in western North America to be reoccupied. For example, Colorado's peregrine population was still in a collapsed state in the mid-1980s, but the number of nesting pairs increased dramatically soon afterwards (Enderson et al. 1988, Craig and Enderson 2004). Similarly, Yellowstone National Park supported just one active peregrine territory from 1984 to 1986, but 11 pairs were present by 1994 (McEneaney 2005).

In north central Utah, some peregrine recovery occurred when hack towers were occupied by breeding pairs, but peregrines 


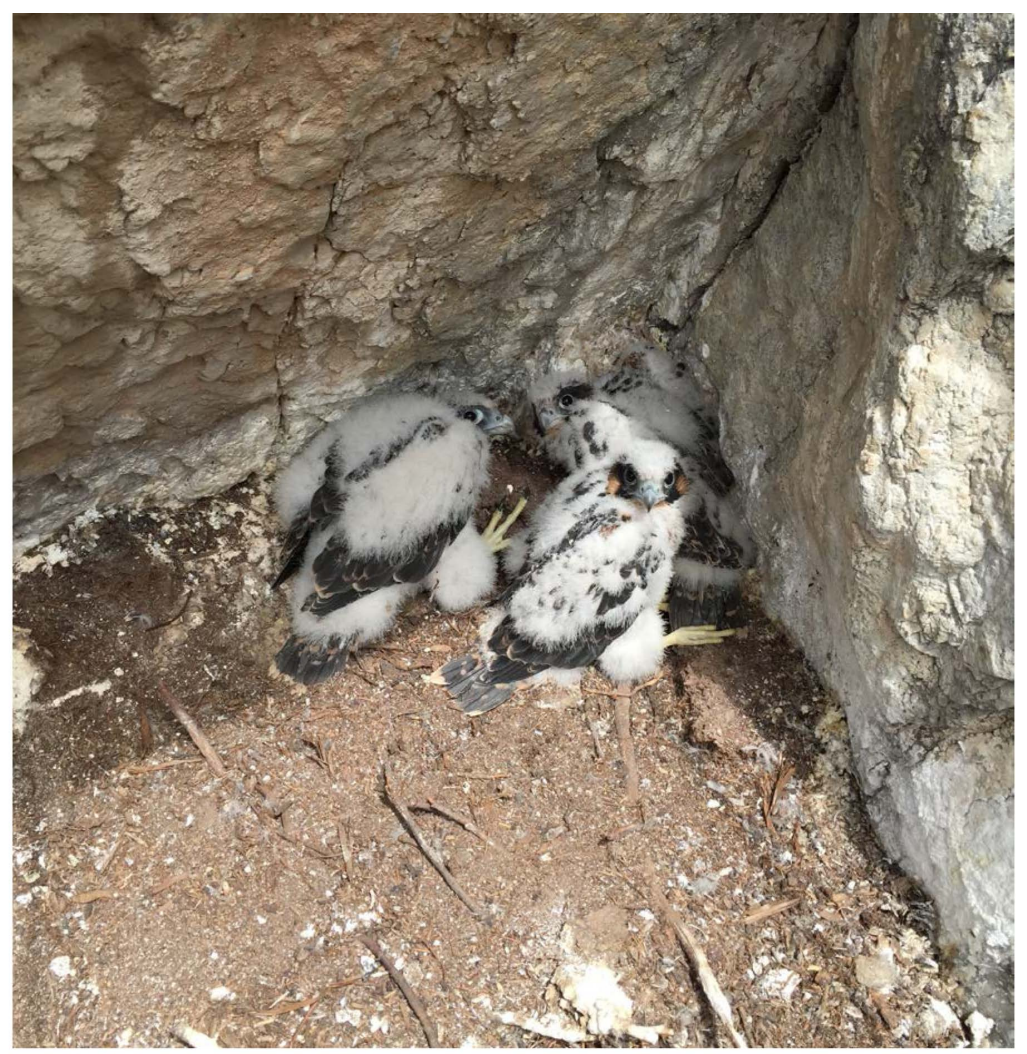

Fig. 3. Peregrine Falcons approximately 25 days old, Rich County, Utah.

were slow to colonize natural cliffs. Based on their 2002 survey, Kozlowski et al. (2009) provided a grim depiction of peregrine recovery in the region. Citing accounts of peregrine numbers by observers prior to the pesticide era, they stated, "Breeding distributions of the Peregrine Falcon from these time periods suggest a much higher historical abundance than found in recent surveys" (Kozlowski et al. 2009:447).

This modern assessment possibly resulted, at least partially, from survey and analysis methodologies that obscured evidence of a more successful, albeit modest peregrine recovery. First, the 10 artificial structures occupied by breeding peregrines in 2002 were not regarded by the authors as part of the natural population (which consisted of only 2 cliff-nesting pairs) and were sometimes omitted from population density statistics.

Second, Kozlowski et al. (2009) compared the limited number of active nest sites $(2$ or 12 , depending on whether artificial nest sites were included) in 2002 to the 22 known nest sites for the entire historical era. But the number of historical territories active in any particular year is actually unknown. Ideal sites may have been active annually, but others are known to have been abandoned and later recolonized (Nelson 1969, Porter and White 1973). Still others, most of them marginal in terms of cliff height, were permanently deserted well before the pesticide era (Nelson 1969, White 1994). Additionally, botulism outbreaks may have reduced the number of breeding pairs in some years (White 1963). Regardless, the number of known historical peregrine territories simultaneously active just prior to the pesticide era was probably no more than 15 .

Finally, Kozlowski et al. (2009) noted that recovery era peregrines show little fidelity to particular cliffs, possibly suggesting that historical Wasatch Front nest sites had become marginalized because of extensive urban growth. The authors, however, missed some 


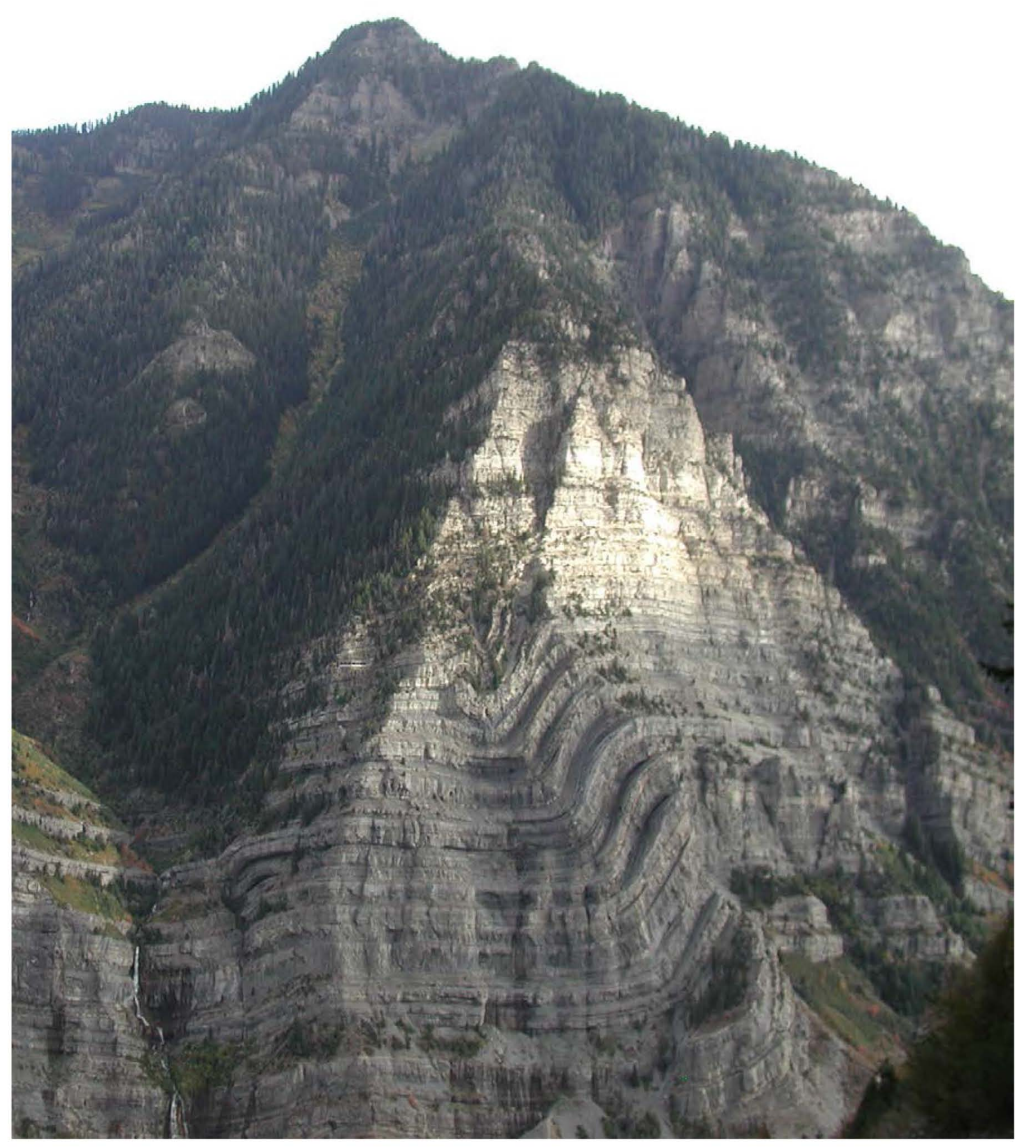

Fig. 4. Peregrine nesting cliff, Provo Canyon, Utah. After 2000, when peregrines nested on a 75-m cliff at the base of the canyon, this cliff, which is nearly $300 \mathrm{~m}$, became a favored nesting site.

active nest sites during their ground and aerial surveys. For example, they incorrectly reported that peregrines ceased breeding in Provo Canyon after 2000. The peregrines, however, had merely moved $4.5 \mathrm{~km}$ to an alternate site (Fig. 4).

The primary purpose of the Kozlowski et al. (2009) survey was to report on the Peregrine Falcon's recovery in northern Utah, emphasizing the extent to which it had recolonized historical nesting cliffs. By that criterion, the peregrine's recovery was, in 2002 at least, negligible. The results of the present study allow for greater optimism.

Eight of 9 peregrine territories (89\%) I visited were active in 2014. This figure is near the upper threshold of the $80 \%-90 \%$ occupancy rate characteristic of healthy Peregrine Falcon populations (Enderson and Craig 1974, Ratcliffe 1988). Since occupancy rates vary, a reasonable figure of occupancy over several years might be $85 \%$. Given this level of activity, there would be approximately 38 breeding peregrine pairs in the study area. Of the 45 peregrine sites recorded during the recovery era, 37 are believed to have been active one or more years during the tenure of this study. Three sites are believed not to have been active during the same period. Information regarding the remaining 5 sites was not obtained. Several sites are known to have had continuous activity for 5 or more years. The Provo Canyon territory was occupied every year of the present study and is believed to have been occupied annually since 2000 (personal observation).

Considering the recent success of the Peregrine Falcon in north central Utah, particularly its occupation of nonhistorical cliffs (Table 1), one could surmise that the historical 
population was larger and more extensive than the recorded history suggests. Indeed, subsequent to Porter and White's (1973) study, the authors learned of several additional peregrine sites from personal communications with birders, falconers and biologists (Clayton M. White personal communication).

While the peregrine population has exceeded established recovery goals, the species is arguably still recovering. The fact that peregrine recovery goals for north central Utah, and other regions of North America, were based on incomplete historical data has been addressed by the U.S. Fish and Wildlife Service (USFWS 1982, 1984).

While it is almost certain that most of the newly reported recovery era nest sites in north central Utah were active at some point during the historical era, it is also likely that some nest sites were not. For example, peregrines have nested on Great Salt Lake's 1.5-km-long Gunnison Island in recent times but not during the historical period. Gunnison's birdlife was monitored intermittently from 1850 to 1915 and almost continuously since the mid-1920s (Behle 1958). While virtually all visitors to the remote island recorded 1 or 2 nesting pairs of Prairie Falcons, they never noted the presence of peregrines. Similarly, 3 canyons in the Wasatch Mountains that now support nesting peregrines were well known among early twentieth-century egg collectors for their Golden Eagle (Aquila chrysaetos) and Prairie Falcon eyries (Bee and Hutchings 1942). These observers made no mention of peregrines even though they regularly visited these canyons and were avid collectors of peregrine eggs.

Scientific investigation of the Peregrine Falcon should continue, given the species' historical significance in the region and the efforts applied towards its restoration. The success of peregrine territories along the highly urbanized Wasatch Front should especially be monitored to determine whether continuing human activities will eventually incur adverse effects.

\section{Addendum}

In 2016, after the research for this paper had been completed, I learned of 2 additional Peregrine Falcon nest sites along north central Utah's Wasatch Front. One is a historical territory in Box Elder County. The other site is a cliff in Salt Lake County that I searched in 2015 , but it was not occupied at that time.

\section{ACKNOWLEDGMENTS}

I thank Clayton M. White, Professor Emeritus, Brigham Young University, and an anonymous reviewer for helpful suggestions regarding the text and organization of this paper. I also express gratitude to Robert E. Walters of the Utah Division of Wildlife Resources for providing data on nesting peregrines.

\section{Literature Cited}

BEE, R.G., AND J. Hutchings. 1942. Breeding records of Utah Birds. Great Basin Naturalist 3:61-90.

Behle, W.H. 1958. The birdlife of Great Salt Lake. University of Utah Press, Salt Lake City, UT.

Brough, R.C., D.L. Jones, And D.J. Stevens. 1987. Utah's comprehensive weather almanac. Publishers Press, Salt Lake City, UT.

Bunnell, S.T., C.M. White, D. Paul, and S.D. Bunnell. 1997. Stick nests on a building and transmission towers used for nesting by large falcons in Utah. Great Basin Naturalist 57:263-267.

Craig, G.R., AND J.H. Enderson. 2004. Peregrine Falcon biology and management in Colorado 1973-2001. Technical Publication No. 43, Colorado Division of Wildlife.

Enderson, J.H., And G.R. Craig. 1974. Status of the Peregrine Falcon in the Rocky Mountains in 1973. Auk 91:727-736.

Enderson, J.H., G.R. Craig, and W.A. Burnham. 1988. Status of peregrines in the Rocky Mountains and Colorado Plateau. Pages 83-86 in T.J. Cade, J.J. Enderson, C.G. Thelander, and C.M. White, editors, Peregrine Falcon populations: their management and recovery. The Peregrine Fund, Boise, ID.

Hickey, J.J., EDITOR. 1969. Peregrine Falcon populations: their biology and decline. University of Wisconsin Press, Madison, WI.

Jackson, R.J., And D.J. Stevens. 1981. Physical and cultural environment of Utah Lake and adjacent areas. Great Basin Naturalist Memoirs 5:3-24.

Kozlowski, A., J. Alston, F. Howe, C. White, and C. Colt. 2009. The status of the Peregrine Falcon in north-central Utah. Pages 445-460 in J. Sielicki and T. Mizera, editors, Peregrine Falcon populationsstatus and perspectives in the 21st century. Turul Publishing and Poznan University of Life Sciences Press, Poznan, Poland.

McEneaney, T. 2005. Yellowstone bird report, 2004. YCR2005-01, National Park Service, Yellowstone Center for Resources, Yellowstone National Park, WY.

Nelson, M.W. 1969. The status of the Peregrine Falcon in the Northwest. Pages 61-72 in J.J. Hickey, editor, Peregrine Falcon populations, their biology and decline. University of Wisconsin Press, Madison, WI.

Pagel, J.E., D.A. Bell, and B.E. Norton. 1996. De-listing the American Peregrine Falcon: is it premature? Wildlife Society Bulletin 24:429-435.

Paul, D. 1985. The Peregrine Falcon: a species newly introduced into northern Utah. Utah Birds 1:70-76.

Porter, R.D., AND C.M. White. 1973. The Peregrine Falcon in Utah, emphasizing ecology and competition 
with the Prairie Falcon. Brigham Young University Science Bulletin 18(1):1-74.

Pritchett, C.L., H.H. Frost, and W.W. Tanner. 1981. Terrestrial vertebrates in the environs of Utah Lake. Great Basin Naturalist Memoirs 5:128-168.

Ratcliffe, D.A. 1970. Changes attributable to pesticides in egg breakage frequency and eggshell thickness in some British birds. Journal of Applied Ecology 7:67-115.

Ratcliffe, D.A. 1988. The peregrine population of Great Britain and Ireland, 1965-1985. Pages 147-157 in T.J. Cade, J.J. Enderson, C.G. Thelander, and C.M. White, editors, Peregrine Falcon populations: their management and recovery. The Peregrine Fund, Boise, ID.

Steenhof, K., M. Kochert, L.B. Carpenter, and R.N. Lehman. 1999. Long-term Prairie Falcon population changes in relation to prey abundance, weather, land uses, and habitat conditions. Condor 101:28-41.

[USFWS] United States Fish and Wildlife Service. 1982. Recovery plan for Peregrine Falcon (Pacific population). Pacific Coast American Peregrine Falcon Recovery Team. USFWS, Denver, CO.
[USFWS] United States Fish and Wildlife Service. 1984. American Peregrine Falcon recovery plan (Rocky Mountain/Southwestern Population). Prepared in cooperation with the American Peregrine Falcon Recovery Team. USFWS, Denver, CO.

White, C.M. 1963. Botulism and myiasis as mortality factors in falcons. Condor 65:442-443.

White, C.M. 1994. Population trends and current status of selected western raptors. Studies in Avian Biology 15:161-172.

White, C.M. 2006. Peregrine quest, from a naturalist's field notebooks. Western Sporting, Ranchester, WY.

White, C.M., AND R.D. PorTer. 1986. Native populations of the Peregrine Falcon in Utah: past and present. Utah Birds 2:10-14.

Received 11 May 2016

Accepted 1 December 2016

Published online 28 February 2017 